Finlandisation or Media Logic? The Estonian-Russian Border Incident of 2014 in Finnish, Estonian, and British Press

Around 9 am on 5 September 2014, Estonian Internal Security Service (KaPo) officer Eston Kohver was captured by agents of the Russian Federal Security Service (FSB) near the Estonian-Russian border crossing of Luhamaa. According to Estonian sources, Kohver was abducted from the Estonian side of the border, while Russian authorities claimed that he had been on Russian soil and was detained for trespassing. A definitive account of the incident is yet to appear, as the interpretation of the events in the two countries remains fundamentally different. In August 2015 Kohver was sentenced to 15 years in prison by a Russian court, amidst protestations from Estonia and the EU that the trial was rigged and that Kohver's imprisonment had been in violation of international law in the first place (BBC, 19/08/15; Reuters, 19/08/15). He was pardoned and exchanged for Aleksei Dressen, a KaPo officer charged with spying for FSB, in September 2015, and returned to Estonia. Whatever the details turn out to be, there is no question that the seemingly small incident created unprecedented tension between Estonia and Russia-and by extension, NATO and Russia.

In neighbouring Finland, the incident hit the headlines right on the day it happened. Finland has close ties to both Russia, with which Finland shares a 1000 kilometre border and from whom it buys around $70 \%$ of its imported energy, and Estonia, with which Finland shares a cultural affinity and vibrant tourist and business connections. The events in Ukraine earlier in 2014, the hardening of Russia-EU relations, and frequent flexing of Russian military muscle (including violations of Finnish airspace) made the border incident a major news item in Finland. 
This article examines the construction of the Estonian-Russian border incident-or the 'Kohver case', as we will refer to it-in Finnish, Estonian, and British press. The focus is on the Finnish data for two reasons: First, Finland provides an interesting case of an outsider in the Estonian-Russian dispute, but an outsider that is deeply entrenched in the politics and culture of both countries. Second, we will examine whether the news reporting of the case conforms to conceptualisations of 'Finlandisation', i.e. self-censorship arising from geopolitical considerations. As we discuss below, Finlandisation encompasses much more than the historical Finnish-Russian relationship and is applicable to forms of discourse and policy in any country. Nevertheless, it seems apt to concentrate on the country that (fairly or not) gave the name to the concept. In order to strengthen our analysis of the Finnish press discourse we will compare and contrast it with examples from Estonia and the UK. This comparison enables us to detect if Finlandisation indeed manifests itself in certain discursive choices. Here we follow an example in comparison set by Alasuutari et al. (2013). Put in question form, our two main enquiries (and their sub-questions) are:

(a) How did the press construct the event and the actors in the reporting of the Kohver case in Finnish, Estonian, and British press? What happened? Who did what? Who was responsible? What is the outcome of these constructions? Are there differences in national reporting? (b) Can 'Finlandisation' explain the discursive choices in the press constructions?

We analyse the press reports using critical discourse analysis (CDA), especially as outlined in John E. Richardson's Analysing Newspapers (2007). Before the empirical analysis, we discuss the meaning of 'Finlandisation' and its usefulness as an analytical category, then outline our methodological toolkit. After analysing the data country by country, we will compare the discourses and, finally, discuss the relevance of the results. In conclusion, we argue that the Finnish news discourse on the Kohver 
incident could be, with some reservations, subsumed under the term 'Finlandisation'. A more fruitful approach, however, would be to consider the discursive differences in the framework of the 'domestication' of news, that is, making (foreign) news 'more familiar, more comprehensible and more compatible for consumption by different national audiences' (Alasuutari et al., 2013). This implies that explaining the tone of the news discourse is as much a matter of media logic as it is of underlying and/or implicit ideology.

\section{Finlandisation and its Discontents}

Initially, 'Finlandisation' did not even refer to Finland. Rather, its usage was 'related to an internal German power struggle, in which a threatening figure of the expansionist Soviet Union was carefully used in the spirit of the Cold War' (Majander, 1999). In the 1960s it was West German Chancellor Willy Brandt's Neue Ostpolitik that incited claims about West Germany becoming a Soviet pawn. Similarly, in 1979, looking at the possibility of left-wing Labour candidate Tony Benn's victory (which never materialised), the right-wing press referred to the imminent Finlandisation of British politics (Singleton, 1981). The Finns, of course, were not happy. Admittedly, many reporters and even scholars used the concept with little knowledge about the actual conditions of Finnish-Soviet relations. Hence, much of the debate around the concept-especially in the Finnish contributionshas since revolved around the historical accuracy of what Finlandisation is supposed to mean.

In the post-World War II international order, Finland's unique position between the Soviet Union and 'the West' was seen by some commentators as capitulating to Soviet influence, constructing a relationship between the two states that ranged from benevolent realpolitik to claims about Finland being 'remote-controlled' by the USSR (Moisio, 2008). This meant, among other things, military 
neutrality and consulting the USSR before joining major European trade agreements. What made Finlandisation as a concept-accurate or not-resonate with the rest of Europe was the image of 'creeping Sovietization: Finland today, the rest of Europe tomorrow' (AUTHORS BLINDED). While the existence of Finlandisation was denied, at least in its most denigrating senses, by Finnish politicians during the Cold War, the 1991 collapse of the USSR inspired a rewriting of history where Finland was indeed said to have been Finlandised (Moisio, 2008). This was later used as a political tool, where people opposed to joining the EU (and hence, 'the West') before the 1995 accession were accused of being 'Finlandised'.

Most relevantly for our purposes, one aspect of Finlandisation is said to include 'restraint over the media in one's country to muffle of minimise criticism of the USSR, so as to avoid possible provocation' (Ginsburgs and Rubinstein, 1978, quoted in Majander, 1999). Esko Salminen's book The Silenced Media (1999) is part of the post-1991 rewriting of Finnish post-war history. It is a strong, if controversial, indictment of the Finnish media during the Cold War years. One of the main players in Salminen's (and others') narrative is President Urho Kekkonen (president 1956-1982), whose persona in many ways embodies the idea of Finlandisation. Critics of Kekkonen 'have suggested that he skilfully manipulated his foreign policy concerns to suit his domestic political interests' (Hilson, 2008), exemplified in the Soviet Union's endorsement of Kekkonen, which led to the failure of an electoral challenge in the so-called 'Note Crisis' in 1961-2. Kekkonen reciprocated by actively directing policy and media discourse about the Soviet Union. More importantly, according to Salminen, the Finnish media was not only directly influenced by key politicians such as Kekkonen, but succumbed to self-censorship in an attempt to toe a Soviet-friendly line (Salminen, 1999). As Hilson (2008) puts it: 'By the 1970s self-censorship was practised widely throughout the mass media, and in some cases it went beyond pragmatic caution to include flattery, embellishment and distortion of truth'. However, as Hilson usefully reminds us, 'although the Finnish political and media 
elite were deferential, the rest of Finnish society was not "Finlandised".... [I]t retained an uncensored cultural and intellectual life' (Hilson, 2008).

The jury is still out on whether Finlandisation even counts as a heuristic concept or a useful 'theory' (Mouritzen, 1988). Many have argued that it has mostly ended up in propagandistic usage (e.g. Majander, 1999). But there are two reasons why the concept can be useful in an analysis of contemporary media texts. First, empirically speaking, Finlandisation has again made a return to public discourse in Finland. Within two weeks of the Kohver case in 2014, the then Minister of the Environment, Ville Niinistö, said that the government's decision to grant nuclear building rights to partly Russian-owned Fennovoima showed that Finland was returning to the times of 'Finlandisation' by putting Russian interests ahead of energy security concerns (Helsingin Sanomat, 17/09/14). In another theme reminiscent of Cold War times, 'Finlandisation' pops up almost always in discussions about Finland joining NATO-something that became a pertinent theme when Russian planes violated Finnish airspace during 2014 (e.g. Uusi Suomi, 03/03/15). Second, the Finlandisation debate, mostly waged in international relations theory, is somewhat different when approached from a media and culture angle. The question, then, is not about whether Finlandisation accurately or objectively describes Finnish-Russian relations, that is, whether Finland 'deserves' to carry the moniker. Rather, in our usage, it is a hypothesis about the effects that the proximity of a major power in the context of international tension has on media discourse and culture more broadly. It is from this position that we proceed with our critical discourse analysis of the newspaper data. 
Our Finnish data consists of 43 articles from the online editions of two Finnish tabloids (IltaSanomat, Iltalehti), Finland's largest broadsheet (Helsingin Sanomat), and the website of the public broadcasting company YLE. ${ }^{1}$ Our Estonian data is comprised of 69 articles from the online edition of Postimees, the country's largest daily newspaper. The British data consists of 13 articles from The Guardian and the Daily Mail-a liberal broadsheet and a conservative tabloid. The focus of the analysis is on the Finnish data, with Postimees and the British papers providing an illustrative contrast, rather than a systematic comparison. As can be noted from the numbers, the event generated broadest coverage-rather obviously-in Estonia, then Finland, and only a couple of mentions in the British press. We collected material from between 5 September 2014 (the date of the event) until 5 March 2015 (six months from the event). For pragmatic purposes and purposes of coherence, we have not included later news about the sentencing and eventual pardon of Kohver in August/September of 2015. Many of these later items repeated the discourses of the initial reports, and our focus is on the construction of events and actors in the immediate aftermath of the event. The choice of data and method shows that our intention is not to make statistical generalisations about the prevalence of particular discourses in the news, nor to discuss national media politics and their effects on news discourse, except in an illustrative manner. Instead, we aim to detect patterns and, if such emerge, contextualise these within the national media and broader social contexts (Fairclough, 1992). The combination of textual and contextual analysis enables us to discuss whether such patterning and its explanations are applicable to other contexts as well.

Our research questions are informed by the basic idea that knowledge about the world is a product of processes of social construction (AUTHOR BLINDED). The media in modern societies are an increasingly important contributor to the construction of knowledge. By selecting which news are

\footnotetext{
${ }^{1}$ Strictly speaking, as the public radio and television provider, YLE is not part of the Finnish 'press'. In this article, we will, however, treat the YLE website as a 'press' platform.
} 
newsworthy in the first place and by (definition) presenting news from particular angles the media shape our view of the world-especially in the case of foreign news, where the audience has little or no experiential knowledge of the issues or events represented. Speaking prophetically in 1995, Allan Luke said: 'the $21^{\text {st }}$-century citizen will work in media-, text-, and symbol-saturated environments. For the unemployed, underemployed, and employed alike, a great deal of service and informationbased work, consumption, and leisure depends on their capacities to construct, control, and manipulate texts and symbols' (Luke, 1995-1996). It is therefore not an exaggeration to say that we live in an age of discourse.

Hence, we have opted to analyse our data using critical discourse analysis (CDA), especially as formulated by Norman Fairclough (1992; 1995) and John E. Richardson (2007). Instead of simply mapping the varieties of discourses, CDA focuses on 'the dynamics of power, knowledge, and ideology that surround discursive processes' (Phillips and Hardy, 2002). In Fairclough's words, CDA analyses the ideological functions of discourse, that is, 'constructions of reality (the physical world, social relations, social identities), which are built into various dimensions of the forms/meanings of discursive practices, and which contribute to the production, reproduction or transformation of relations of domination' (Fairclough, 1992). By doing so, CDA aims to uncover how and why particular ways of talking about things become dominant while suppressing alternative views.

There are a variety of methodological 'toolkits' available to analysts drawing from the critical constructionist tradition of CDA. Since we firmly believe that every discourse analytical study needs to be tailored to its particular needs, and since the apparatus is pragmatically restricted by the amount of data, we will focus on four aspects of the media discourse: (a) lexis, or word choice, (b) transitivity, or the discursive assignment of agency, (c) modality, or the presence (or absence) of the 
reporter's or media's voice, and (d) narrative, the macro-level organisation of meaning (cf. Richardson, 2007).

Lexis refers to the analysis of word choice. Words are central to CDA, because they contextualise events and actors. For example, on reporting the 1991 war in Iraq, British journalists used 'destroy' and 'kill' whenever speaking of Iraqi actions, whereas US and UK troops were 'suppressing', 'eliminating' and 'neutralizing' (Richardson, 2007). These (and many other contrasting word choices) create a sense of 'us' and 'them', and in this case depict the actions of western troops as mechanical dehumanised responses rather than a conscious aim to hurt an enemy.

The analysis of transitivity is the key to understanding representation of agency in discourse (Richardson, 2007). The choice of active and passive agent (someone who does and someone to whom things are done to), and especially the deletion of agency altogether has significant effects in how causes and reasons for actions are constructed in discourse. A classic example is the attribution of action in events: 'Police shoot demonstrators' is an active construction, while 'demonstrators are shot by the police' is a passive construction. The difference of the two is in the emphasis: in the first one the police are the active actors, in the latter, the demonstrators. In some cases the actor is deleted completely, as in 'demonstrators are shot', a common technique in newspaper discourse (Fairclough, 1992; Richardson, 2007). Further, agency can be muddled through what Fairclough calls 'nominalization'. Here an active verb is transformed into a passive noun or adjective. As Richardson (2007) puts it, saying that 'capital is mobile' masks the agency in the movement of global capital, which does not move by its own volition. Instead, an active construction would be to say that 'companies move capital around the globe'. 
The term modality is used in CDA for the ways in which the 'speaker or writer is committed to the claim that he or she is making' (Richardson, 2007). Goffman (1981) calls this 'footing', referring to the 'range of relationships that speakers and writers have to the descriptions they report' (Potter, 1996). Modality is usually indicated by the use of modal verbs (e.g. may, could, should), their negations (e.g. couldn't, shouldn't), adverbs (e.g. certainly), and categorical language (e.g. will, must, certainly). Beyond the sentence level, modality and footing refer to the voice of news discourse, that is, whether a claim is made in the reporter's/media's own voice, or through the mouth of people quoted in the story.

In CDA, analysing narrative refers to the unfolding of a story: they 'establish relationships between or among things (e.g. events, states, situations) over time' (Jasinski, 2001, quoted in Richardson, 2007). In our schema this includes two things: First, narrative contextualises events in the news discourse. In the Kohver case the key contextualisations related to the question of the political nature of the incident (see below). Second, the analysis pays attention to the difference between narrative content (the sequence of events as they occurred) and narrative form (the sequence of events presented in discourse). The relationship between the two draws attention to how the truth claims of the narrative are constructed.

On the practical level, the analysis was a collaborative project (AUTHOR BLINDED; Bruffee, 1993). We divided the corpus for close reading, then offered individual interpretations of patterns of discourse in the data. These were collaboratively discussed, developed, and modified. Rewriting the analysis continued until the data did not offer new interpretations and until we were in agreement with the existing interpretations. Although CDA cannot, by definition, be 'objective' in the strict 
sense, collaborative text analysis offered us a chance to check one's interpretations against fellow analysts' interpretations, pointing out subjective biases (Nikander, 2008).

The Kohver Case in the Finnish Press

When the news about the border incident started unfolding in early September 2014, the Finnish media followed the case intensely. The claims of the Estonians and Russians were diametrically opposed, and despite an attempt to seem neutral in reporting both sides of the story when all that was known of the facts was what the parties commented, a close reading the constructions of the case suggests what we have termed lexical and narrative sympathy towards Kohver and the Estonian side.

The most commonly used word for the event was 'abduction' (sieppaus), or even 'kidnapping' (kaappaus) in some cases (e.g. Ilta-Sanomat, 05/09/14; Iltalehti, 13/09/14; Helsingin Sanomat, 06/09/14). 'Abduction' carries a connotation that the Estonian side of the story is the true oneKohver was abducted from Estonian soil-and points an accusing finger to one party, instead of using a more neutral word which could have been more appropriate in this early stage of the event when the reports from the two sides were clearly conflicting. Interestingly, 'abduction' remained the word of choice even for later news, when more facts of the case had been uncovered and both sides of the story had been heard (IIta-Sanomat, 28/01/15; YLE, 31/10/14).

In another lexical choice, Kohver was consistently referred to as an Estonian 'policeman', 'officer' (e.g. YLE, 17/09/14; Helsingin Sanomat, 17/09/14), or even 'official' (e.g. Helsingin Sanomat, 
08/09/14). Although the Russian side claimed that information gathering paraphernalia and a handgun had been found on Kohver's person, the word 'spy' only came up in reference to Russian accusations. Part of the explanation for the word choice can be found in the fact that while the events were unfolding, the Finnish media-the tabloids especially-were dependent on news releases in Estonian Postimees. The rapid reporting of online news was in the beginning very much a case of translating Estonian news into the Finnish language rather than applying investigative journalism.

The apparent toeing of the Estonian line cannot, however, be completely explained by reporting conventions. A telling instance from the tabloid IIta-Sanomat (05/09/14) also suggests a 'narrative sympathy', in addition to the lexical bias. The story was built around an article published by the Russian news agency Itar-Tass, which was a response to an earlier press release by the KaPo. In the Itar-Tass story the FSB claimed that the incident took place on the Russian side of the border. The story also used rather neutral lexis - compared to 'abduction' — to describe what happened: Hence, Kohver was 'arrested' and 'ended up' in Russian hands. Later, similar lexis-Kohver was 'taken' and 'imprisoned' - was used by, for example, Helsingin Sanomat (08/09/14), in reporting the Russian view. However, the very last sentence of the 5 September IIta-Sanomat article said that 'the case happened at 9 am near the Luhamaa border crossing in South-East Estonia'. This could be simply a slip, but what is important from a discursive perspective is not the intention of the authors and their success in conveying the message, but the impression that article potentially leaves: that despite Russian claims (narrative form), the event happened on the Estonian side (narrative content).

The most glaring example of narrative sympathy was published, perhaps surprisingly, not in the tabloids, but in Finland's biggest daily broadsheet, Helsingin Sanomat: 
Kohver is being kept in Moscow in Lefortovo prison. The prison has been described as especially notorious, and during Soviet times its name had an echo as bad as the KGB's Lubjanka headquarters. Matthias Rust, the German pilot who landed on the Red Square, was also kept in Lefortovo (Helsingin Sanomat, 08/09/14).

By invoking Soviet times and the infamous KGB, the Helsingin Sanomat story creates a particularly sinister tone to the case. Similar Cold War tones were voiced by Estonia's Foreign Minister and Ministry officials - and echoed by the Finnish press - when Kohver declined the use of Estonian appointed defence counsels, and was suspected of being pressured (possibly by using force) to do so by the Russians (IIta-Sanomat, 17/09/14; Helsingin Sanomat, 17/09/14).

If looking at word choice and narrative constructions can be interpreted as providing sympathy for the Estonian case, other discursive choices paint a more mixed picture. We call this transitive and modal hedging.

In terms of transitivity, especially the early reports frequently passivize the described actions: Kohver 'was abducted' (siepattiin), 'was kidnapped' (kaapattiin), and 'was arrested' (pidätettiin). Nowhere is anyone doing the abduction, arresting, and so on. Unlike the examples given by Richardson (2007) regarding the masking of agency in the 2003 invasion of Iraq, where the actions of the coalition forces were presented as passive reactions to active enemy action, there is little justification for reading such bias into the reporting of the Kohver case. First, the passive constructions can be argued to be a function of journalistic conventions at a time when facts were blurry (to say the 
least). Second, the passivization applies equally to reporting of claims from both sides of the conflict. As such it could be considered neutral. Indeed, the nominalization of 'was abducted' into 'the abduction' in later reporting (e.g. I/ta-Sanomat, 28/01/15) would support the lexical and narrative sympathy argument above.

However, an alternative reading is possible: by overwhelmingly masking agency in the stories, Finnish reporting avoided attributing blame for the incident on either side. This is intimately tied with the modal choices in the news discourse. 'According to' was heavily used throughout the reporting, and especially in the initial stages. With this kind of 'footing' (Goffman 1981; Potter 1996) the press avoided taking an overt stand on the issue. When opposing stories were reported, the claims were consistently reported through the mouths of officials and official press releases. When expert opinion (another type of footing) was sought on the broader picture, Ilta-Sanomat (28/01/15) quoted famously anti-Russian novelist Sofi Oksanen in its later analysis of the case. Paradoxically, the effect of this could be the opposite of the intended: the message is diluted when it is easy to show that the messenger is biased. Overall, the hedging transitive and modal constructions could be said to dilute, if not completely counter, the lexical and narrative sympathy discussed above.

In sum, it cannot be conclusively shown that the discursive form of reporting about the Kohver case was somehow Finlandised. The transitive and modal constructions suggest a cautious approach by the press, which could be interpreted as echoing the caution of the Cold War years. However, in light of journalistic conventions it would be premature to claim that this was a clear case of Finlandisation-and certainly there is no evidence of conscious all-encompassing self-censorship that Salminen (1999) argues was the norm of Finlandised media. Further, the lexical and narrative forms suggest what we have termed 'sympathy' for the Estonian case. 
However, broadening the scope beyond the form to the contextual meaning of discourse, it can be argued that the discourse works ideologically by omitting particular perspectives. The assumptions of 'common sense' and, in this case, the 'appropriate' style of reporting, are most clearly shown not in what is said, but in what is not said (Fairclough, 1989). The absence of the political contextualization-or depoliticisation (Bourdieu, 2002) - of the Kohver case is rather striking, especially in comparison with the British press (see below). There is no mention of Ukraine or recent Russian airspace violations. Russia as a political actor is more or less absent, and little in terms of background or the broader scope is attempted-particularly in the tabloids which in any case reported the incident only several times, in contrast to the continuous follow-ups in Helsingin Sanomat and YLE. The connection with recent EU sanctions, NATO, or Obama's timely visit to Estonia and the Kohver case is made three times. First, through the mouths of 'many security policy and Russian experts' ('useiden turvallisuuspolitiikkaan ja Venäjään perehtyneiden asiantuntijoiden mukaan'; Helsingin Sanomat, 10/09/14); second, through the mouth of a New York University professor (I/talehti, 13/09/14); third, through the mouth of The New York Times (IItalehti, 06/10/14). In all instances, modal hedging is apparent, effectively distancing the paper from the expressed opinion. All this might be a function of the focus on online stories, which emphasize event reporting rather than contextualisation. Nevertheless, it raises the question as to why exactly was the political context that features so prominently in British news not brought up.

\section{Estonian Press Constructions of the Kohver Case}

Of the three news contexts studied in this article, the Estonian was, unsurprisingly, the most immediate and numerous in terms of reporting. The stories in Postimees also had several features 
not found in the Finnish or the British news. The construction of the case in Postimees also followed slightly different lines in discursive terms.

First of all, the Postimees reporting shared the lexical and narrative sympathy of the Finnish news reports discussed above. What was at stake was an 'abduction' and Postimees quite clearly took the side of the initial KaPo press release, for example in the initial story on the day of the event, where words like 'abduction' (röövimine), 'capture' (kinnivõtmine) and 'kidnap' (inimrööv) were used (Postimees, 05/09/14). Even when Postimees is describing how Russian media covers the event, words 'capture' and 'taken at gunpoint' (viisid relva ähvardusel) were used (Postimees, 05/09/14) and the lexical sympathy towards the Estonian security police officer does not disappear even months after the event when the phrase 'drag to Russia' (Venemaa poolele vedama) was used in an article published on 31 $1^{\text {st }}$ December 2014.

In terms of transitivity, unlike the Finnish newspapers discussed above, Postimees uses active voice from the very beginning of the reporting. While Finnish newspapers frequently passivized the actions - 'was abducted' (siepattiin), 'was kidnapped' (kaapattiin), and 'was arrested' (pidätettiin)— these verbs clearly had an agent in Postimees. In early days capturing was done by 'unidentified people who entered Estonian territory from Russia' (Postimees, 05/09/14; 06/09/14), 'people who crossed the border illegally' (Postimees, 05/09/14), and 'Russian Federal Service' (Postimees, 06/09/14).

In terms of narrative, the Postimees reporting also supported the Estonian side of the story (again, rather unsurprisingly), but added elements missing from the Finnish press. For example, a significant number of articles discussed Eston Kohver's health. The title of an article published after the 
imprisonment of Kohver in Lefartovo prison drew attention to the officer's health: 'Kohver claimed to have good health condition during a meeting with consul' (Postimees, 20/11/14). In the same article it is also said that 'Russian authorities have not replied to the application submitted by Estonia to have an Estonian doctor carry out medical examination' and that all meetings between Kohver and consul are 'supervised by prison workers', which may implicate that even though Kohver claimed to be in good health, he could not speak freely. In addition, other articles, which were not focusing on his health, implied maltreatment or even torture. When Kohver declined the defence lawyer nominated for him by Estonia, Estonian minister of foreign affairs Urmas Paet claimed that Kohver is not free to make his own choices and Mark Feigin, whose defence counsel Kohver declined, said that Kohver's situation is in reality very bad (Postimees, 17/09/14). Discursively speaking, these are not only narrative techniques, but also examples of presupposition, or tacit assumptions made in the text (Richardson 2007). Drawing the attention to Kohver's health has, on the outside, obvious news relevance for his family and associates, but also implies that discussing his health is relevant because the presupposition is that the Russian authorities might be treating their prisoners badly. Another narrative issue supporting the sympathy position was the construction of Kohver as a sort of folk hero. Several of the stories mentioned that in 2010 the Estonian president awarded Kohver with a badge of merit for services to national defence (e.g. Postimees, 05/09/14).

If the case for Finlandisation in the Finnish press hung on the absence of particular discourses-in this case, the political context of the event-the Postimees reporting depoliticised the case explicitly. Hence, speaking of 'narrative sympathy' is only part of the story. Narrative in the Estonian press example worked both ways: it (again, unsurprisingly) took the Estonian side, but at the same time vehemently avoided embroiling the event in broader political tensions between Estonia and Russia. The press release of the Estonian security police on the night of (what they referred to as) the abduction underlined that it was not a political, but a criminal act. Postimees faithfully toed this line. 
Later, Estonian security expert Jaanus Rahumägi commented that it was originally not a political act but after it was made public it got a political connotation (Postimees, 07/09/14):

'This incident is a normal working incident, which had no political background or intention to provoke Estonia or NATO. It has gotten a political connotation after it was made public', thought Rahumägi, the previous head of Estonian Internal Security police. Russia is now taking advantage of the incident to create propaganda against Estonia.

Another article interviewed Estonian foreign minister Urmas Paet and Estonian defence minister Sven Mikser who were attending a NATO summit in Wales at the time of the abduction. Both of them treated it only as a criminal case and would not connect it with NATO (Postimees, 05/09/14):

'Based on the information we currently have about what happened to the KaPo officer on the Estonian border, it needs to be treated as a criminal act' said Paet, 'knowing the information we have today, I would not draw parallels [with a political act]'. According to Mikser he has not discussed the topic with his NATO colleagues. 'In Estonia the public prosecutor's office deals with criminal proceedings and the KaPo officer worked within the jurisdiction of the Minister of Internal Affairs,' he explained.

This (de)politicisation of the event in Postimees is complex: on the one hand the narrative dilutes the lexical and narrative sympathy constructed earlier, but the modal choices-unlike in the Finnish case-can be argued to support the sympathetic case. When Postimees effectively chose to speak through other people regarding the politics of the event, they were saying that these people claim 
that there is no connection, yet we leave the interpretation up to the reader. The unpolitical nature of the event is not a fact, it is the opinion of reports, experts and politicians. An important and relevant opinion, but an opinion nevertheless.

\section{The Kohver Case in the British Press}

While the Kohver case was a main item for the much of the autumn of 2014 in Estonia, and received broad coverage in the Finnish press, it faded quickly in the British press. What is interesting and significant is the rather different tone and style adopted in the British press in comparison to the Finnish and Estonian coverage.

In The Guardian and the Daily Mail the sympathies were definitely with the Estonians, but the political aspects of the event were highlighted to an extent not seen in the coverage from the other countries. The lexical and narrative constructions went beyond sympathy, and there was very little in terms of hedging, either transitively or modally-even in the early days after the incident. There was a far stronger tone of authority in the British reports than is ever present in the Finnish coverage.

The Daily Mail's initial story (05/09/14) - based on a Reuters communique-about the incident mentioned the conflicting explanations given by Estonia and Russia: Estonians say that Kohver was 'abducted', while Russians use the term 'detained'. However, the narrative and the broader contextualisation of the event were sympathetic to the Estonian case. The FSB was identified as the 'successor to the Soviet KGB', which conjures echoes of the Cold War. Similarly, the contextualisation of the case as a case of 'us and them' was rather blatant: 
Relations between Russia and Estonia, an ex-Soviet state and member of the EU and NATO, have deteriorated in recent months because of Russia's annexation of Crimea and a proRussian separatist rebellion in eastern Ukraine... On Wednesday, U.S. President Barack Obama visited Estonia on his way to a NATO summit to assure it and the other two Baltic states, Lithuania and Latvia, of NATO's support (Daily Mail, 05/09/14).

While the final paragraphs convey the Estonian view that the incident was unpolitical, the positioning of Estonia as a front in a broader EU/NATO vs. Russia conflict is clear. Two days later, there was no evidence of even this kind of hedging. The 7 September Daily Mail headline summarised the story and its perspective comprehensively: 'Estonian "spy" found with pistol, cash and "recording equipment" is kidnapped in his home country by Russians and now faces 20 years in Moscow jail'. Using scare quotes around 'spy' questions the Russian perspective, and 'kidnapped in his home country' builds a strong case for seeing Russia as the culprit in the case.

It is tempting to explain the Daily Mail's tone with the propensity of tabloids for catchy and selling discourse. However, the lexis and the narrative of The Guardian showed equal sympathy to the Estonian case. Despite initially reporting the Russian view of the event, 'abduction' soon became the standard for speaking about what happened to Kohver. Cold War rhetoric surfaced repeatedly in The Guardian's discourse, most strongly in the 7 September story titled 'Russians open new front after Estonian official is captured in "cross-border raid"'. Not only was the event described as opening a 'new front' as in military terms, but the narrative leaves no doubt that the event is part in a chain of events signalling the return of the Cold War: 
The Estonian-Russia border at Luhamaa does not look like a new Checkpoint Charlie. Set among the wooded plains that mark Nato and the European Union's eastern-most territory, the crossing is more likely to be the site of long lines of idling lorries than machine-gun nests and prisoner exchanges. But that era of post-cold war calm may have come to an end on Friday morning, when, according to several Estonian accounts, smoke grenades detonated at an Estonian customs post, and all radio and telephone signals were jammed as armed Russian men suddenly materialised and dragged away a local official (The Guardian 07/09/14b).

The active agents in the Guardian story are the 'Russian men', who turn out to be FSB agents. The transitive effect is supported by a narrative contextualisation where the FSB is unambiguously identified with the KGB:

[A]lthough the KGB fled the Viru [hotel], it never altogether left Estonia. Its successor, the Federal Security Bureau (FSB), has remained highly active in Estonia and its Baltic neighbours, Latvia and Lithuania - increasingly so recently as Russia seeks to reassert its sway over what it calls the "near abroad" (The Guardian, 18/09/14).

The broader contextualisation of the event as part of recent political tensions is similarly unambiguous: 
Kohver's arrest came just two days after a landmark visit by Barack Obama to Tallinn, aimed at reassuring jittery Baltic states of his country's commitment to their security as Nato allies in the face of Russia's role in the Ukraine crisis (The Guardian, 07/09/14a).

[T]he immediate reaction of the government in Tallinn was to play down Friday's incident in the hope that it was the work of local Russian commanders who have a record of involvement in the smuggling trade. The Kapo chief, Arnold Sinisalu, issued a statement saying there appeared to be no political motivation behind the incident. (The Guardian, 07/09/14b).

In major contrast to the Estonian reporting, which simply reiterated the Estonian politicians' depoliticisation of the event, The Guardian argued that the authorities' assessment of the situation was a mistaken or misleading. Indeed, when doubts were voiced, the discourse took a step back in terms of footing/modality, and used a security expert's voice:

"The Kohver abduction was possibly political and symbolic, as it happened the same day as the Nato summit in Wales and a day after Obama's visit to Estonia," [researcher Kalev] Stoicescu said. "But there may be more prosaic reasons connected to the FSB's own relations with the underworld and smuggling across the Estonian frontier." (The Guardian, 03/10/14).

Overall, in The Guardian -as in the Daily Mail-the Kohver case was woven into a broader fabric of worsening relations with Russia and the EU and NATO, and this perspective was reflected in the 
choice of words, transitivity, modality and narrative: it was an abduction where the Russians were the active agents. Both newspapers reported this with much less modal hedging than the Finnish and Estonian papers, and the contextualisation of the case invoked the Cold War.

\section{Conclusion: Finlandisation or Media Logic?}

Our first task in this article was to analyse how the press constructed the event and actors in the reporting of the Kohver case, and what differences there were between the different national news outlets. We have shown above how much of the Estonian discourse on the case was taken up by the Finnish press. Partly this was because of the demand for quick updates and a reliance on translations, but even when the case developed, the Finnish press showed what we have called lexical and narrative sympathy to the Estonian side of the story. At the same time, the transitive and modal constructions of the case (muddling of agency, delegating voice to experts and secondary sources) could be argued to have diluted the sympathetic tone. CDA's double focus on meaning and form was helpful here, as the study of linguistic aspects of the news discourse enabled identifying patterns that would not have been evident in a strictly narrative analysis.

One of CDA's aims is to assess whether discourse can be said to function ideologically, that is, by constructing a hegemonic discourse that suppresses alternative interpretations. This was perhaps ambiguous in terms of the form of what was said, but less so in terms of what was not said. In the Kohver case this had to do first and foremost with the contextualisation of the case within a broader international relations frame. The British press discourse stood out in this sense by reporting the case primarily within this frame. The Estonian discourse-echoing official press releases-explicitly denied the political connection. In a way, however, the depoliticisation of the event was taken 
furthest in the Finnish press, which avoided discussing the political context almost completely. The few times it did, it did so through the mouths of others in a classic exercise of 'footing'.

Depoliticisation is not about denying the political context of the event-like the Estonian press didbut about not properly acknowledging one exists in the first place. Finland's position on the fence between Estonia the NATO country and Russia can be argued to be reflected in the ways in which the political significance (or lack thereof) of the Kohver case was treated in the press. The heightened tension in the Baltic, and Finland's traditional outlook as neutral arbiter on the world stage, was the external or international context for the news discourse. The internal or domestic context, in turn, was the ongoing discussion about NATO membership and partnership-a topic which continues to divide the country. For a press report to take a side in this debate means engaging a complex and highly-charged topic, and while some major Finnish news outlets have been trumpeting the benefits of a NATO membership for some time, the appearance of partisanship in supposedly 'objective' news remains a credibility risk.

This leads to our second task, which was to discuss whether 'Finlandisation' could be useful as a heuristic concept in explaining the differences in discourse. In comparison with the Estonian and, especially, the British discourse, there are some grounds for arguing that the depoliticisation of the Finnish reporting reflects a Finlandised attitude towards Russia. We are not claiming that this was a conscious line taken by reporters and editors, like Salminen (1999) suggests in his polemic. In fact, methodologically strictly speaking, we couldn't do so with just the textual material. It is impossible to attribute motivations from reading texts alone, and further ethnographic research, for example, would be required to talk about a 'silenced media'. It is, however, possible to argue that the broader cultural context influences the ways in which reporting about events like the Kohver case are 
conceptualised in the first place, and that this is reflected in the news discourse. So, if we were to use the depoliticisation of the news discourse as an example of Finlandisation, we would do so in a broader sense from the original use of the concept. Instead of recognisable political processes where Finlandisation is manifest, the 2010s Finnish media discourse would be an example of a diffused cultural type of Finlandisation.

However, even if we accept this refocusing of 'Finlandisation' in a more cultural sense, there are good reasons to question its usefulness - at least when it comes to assessing media discourse. This is so simply because there is no objective yardstick with which to evaluate the extent of Finlandisation, or lack thereof. Yes, in comparison with the British press, the depoliticisation of the Finnish news discourse raises questions. But the politicisation of the British news discourse is itself a function of the newsworthiness, or more accurately, the domestication of news (Lester 1980; Clausen 2004; Alasuutari et al., 2013) Newsworthiness not only explains why the Kohver case did not justify sustained coverage in the British press; it also explains the contextualisation of the case in political terms, because those are the only terms in which the story is relevant for the British public (cf. Shoemaker et a. 1991). Politicisation and depoliticisation are always relative to the context of the news discourse, and hence as much, if not more, a function of media logic as they are a consequence of ideological choices and environments.

\section{References}

Alasuutari P, Qadir A and Creutz K (2013) The Domestication of Foreign News: News Stories Related to the 2011 Egyptian Revolution in British, Finnish, and Pakistani Newspapers, Media, Culture \& Society, 35(6): 692-707. 
Bourdieu P (2002) Against the Policy of Depoliticization, Studies in Political Economy, 69(1): 31-41.

Bruffee K A (1993) Collaborative Learning: Higher Education, Interdependence, and the Authority of Knowledge. Baltimore: Johns Hopkins University Press.

Clausen L (2004) Localizing the Global: 'Domestication' Processes in International News Production, Media, Culture \& Society, 26(1): 25-44.

Fairclough N (1989) Language and Power. London: Longman.

Fairclough N (1992) Discourse and Social Change. Cambridge: Polity Press.

Ginsburgs G and Rubinstein AZ, eds. (1978) Soviet Foreign Policy Toward Western Europe. New York: Praeger.

Goffman E (1981) Forms of Talk. Oxford: Basil Blackwell.

Jasinski J (2001) Sourcebook on Rhetoric: Key Concepts in Contemporary Rhetorical Studies. Thousand Oaks, CA: Sage. 
Lester M (1980) Generating Newsworthiness: The Interpretive Construction of Public Events, American Sociological Review, 45(6): 984-994.

Luke A (1995-1996) Text and Discourse in Education: An Introduction to Critical Discourse Analysis, Review of Research in Education, 21: 3-48.

Majander M (1999) The Paradoxes of Finlandisation, The RUSI Journal, 144(4): 76-83.

Moisio S (2008) Finlandisation Versus Westernisation: Political Recognition and Finland's European Union Membership Debate, National Identities, 10(1): 77-93.

Mouritzen H (1988) Finlandization: Towards a General theory of Adaptive Politics. Avebury: Ashgate.

Nikander P (2008) Constructionism and Discourse Analysis, Handbook of Constructionist Research, New York: The Guilford Press, pp. 413-428.

Phillips N and Hardy C (2002) Discourse Analysis: Investigating Processes of Social Construction. Thousand Oaks, CA: Sage. 
Potter J (1996) Representing Reality: Discourse, Rhetoric, and Social Construction. London: Sage.

Richardson JE (2007) Analysing Newspapers: An Approach from Critical Discourse Analysis. Basingstoke: Palgrave.

Salminen E (1999) The Silenced Media: The Propaganda War between Russia and the West in Northern Europe. London: Macmillan.

Shoemaker PJ, Danielian LH, Brendlinger N (1991) Deviant Acts, Risky Business and U.S. Interests: The Newsworthiness of World Events, Journalism \& Mass Communication Quarterly, 68(4): 781-795.

Singleton F (1981) The Myth of "Finlandisation", International Affairs, 57(2): 270-285. 